\title{
Kebersihan Diri dan Sanitasi Rumah pada Anak Balita dengan Kecacingan
}

\section{Personal Hygiene and House Sanitation among Children Under Five Years Old with Helminthiasis}

\author{
Ririh Yudhastuti, M. Farid D. Lusno
}

Departemen Kesehatan Lingkungan Fakultas Kesehatan Masyarakat Universitas Airlangga

\begin{abstract}
Abstrak
Di Indonesia, prevalensi kecacingan berada pada kisaran $45 \%$ - $65 \%$ dan masih merupakan masalah kesehatan masyarakat yang penting. Berbagai cacing yang menginfeksi anak berusia di bawah 12 tahun dengan prevalensi tinggi meliputi Ascaris lumbricoides, Trichuris trichiura, Ancylostoma duodenale, Necator americanus, dan Enterobius vermicularis. Infeksi cacing perut diduga menyebar melalui sanitasi lingkungan dan higiene perorangan yang buruk. Penelitian ini bertujuan untuk menganalisis hubungan antara lingkungan rumah dan kejadian kecacingan pada anak di bawah lima tahun (balita). Penelitian dilaksanakan pada anak balita di Kampung Keputih Kecamatan Sukolilo Surabaya selama bulan Maret - Mei 2010 dengan desain penelitian kasus kontrol terhadap 51 kasus dan 51 kontrol. Pengumpulan data melalui pemeriksaan laboratorium, wawancara, dan observasi. Analisis data dengan uji chi square dan regresi logistik. Prevalensi kejadian kecacingan dengan pemeriksaan tinja pada anak balita adalah $9,8 \%$. Faktor yang berhubungan dengan kejadian kecacingan pada anak balita adalah keberadaan sarana sanitasi (jamban) $(O R=5,245)$, kebiasaan buang air besar $(B A B)(O R=4,821)$, masih adanya lantai tanah $(O R=$ $5,342)$, kebiasaan cuci tangan setelah $B A B(O R=4,654)$, dan pengetahuan ibu tentang kecacingan $(\mathrm{OR}=2,425)$. Disarankan untuk pengadaan jamban yang memenuhi syarat kesehatan dan plester rumah, meningkatkan penyuluhan pada orang tua balita dan kader kesehatan tentang kejadian kecacingan.
\end{abstract}

Kata kunci: Lingkungan rumah, kecacingan, anak di bawah lima tahun

\section{Abstract}

In Indonesia, helminthiasis is still a public health problem due to its prevalence. The prevalence is $45 \%-65 \%$. The species of helminthes whom infecting children under 12 years old are Ascaris lumbricoides, Trichuris trichiura, Ancylostoma duodenale, Necator americanus, and Enterobius vermicularis. It suspected that infestation of helmint can transmit through lack of environment sanitation and personal hygiene. The objective of research was analyze an association between housing environmental and helminthiasis among students of early childhood age. This research conducted since March until May 2010 with case control design and sample size was 51 subjects for cases and 51 subjects for control. Data analysis used chi square test and logistic regression. The prevalence of helminthiasis with feces examination among the students was $9,8 \%$. The factors associated with helminthiasis were presence of latrines $(O R=5,245)$, defecation habits $(O R=4,821)$, type of floor $(O R=5,342)$, washing hands after defecation $(O R=4,654)$, and parental knowledge $(O R=2,425)$. It's appleated to provide a close with good standard of environmental health, making the cement floor, increase knowledge about helminthiasis and the risk factors

Key words: Housing environmental, helminthiasis, children under five years old

\section{Pendahuluan}

Dalam membangun sumber daya manusia (SDM) yang berkualitas terutama pada anak-anak di bawah lima tahun (balita) sebagai penerus bangsa, harus menjadi perhatian serius. Sesuai konsep paradigma sehat yang berorientasi pada kesehatan masyarakat maka harus diupayakan pencegahan penyakit dan pemeliharaan kesehatan. Di Indonesia, masih banyak penyakit yang menjadi permasalahan di dunia kesehatan, di antaranya adalah cacing perut yang ditularkan melalui tanah. Kecacingan lebih banyak menyerang anak-anak karena aktivitas mereka yang lebih banyak berhubungan dengan tanah. Kecacingan memang tidak membahayakan nyawa, na-

Alamat Korespondensi: Ririh Yudhastuti, Departemen Kesehatan Lingkungan Kampus C FKM Universitas Airlangga, Jl. Mulyorejo Surabaya 60115,

Hp.08165422697,e-mail: yudhastuti_r@unair.ac.id 
mun mampu membuat kualitas hidup penderitanya turun drastis karena dapat menurunkan kondisi kesehatan, gizi, kecerdasan, dan produktivitas penderitanya sehingga secara ekonomi dapat menyebabkan kerugian. Selain itu, dapat menyebabkan kehilangan karbohidrat, protein serta darah sehingga menurunkan kualitas SDM. ${ }^{1-3}$ Pada infeksi berat (hiperinfeksi), terutama pada anak-anak, dapat terjadi gangguan pencernaan dan penyerapan protein sehingga penderita mengalami gangguan pertumbuhan dan anemia akibat kurang gizi. Cairan tubuh cacing yang beracun dapat menimbulkan gejala mirip tifoid, disertai tanda-tanda alergi misalnya urtikaria, edema pada wajah, konjungtivitis, dan iritasi pernapasan bagian atas.

Kecacingan di Indonesia masih merupakan masalah kesehatan masyarakat karena prevalensinya masih sangat tinggi antara $45 \%-65 \%$. Bahkan di area tertentu yang sanitasinya buruk, prevalensi kecacingan dapat mencapai $80 \% .^{2}$ Cacing-cacing yang menginfestasi anak dengan prevalensi tinggi adalah cacing gelang (Ascaris lumbricoides), cacing ini tersebar luas di dunia, terutama daerah tropis dan subtropis yang kelembaban udaranya tinggi, berwarna putih kecoklatan atau kuning pucat, berukuran $10-31 \mathrm{~cm}$, telur berbentuk lonjong berukuran 45 - 70 mikron x 35 - 50 mikron. Selain itu, terdapat cacing cambuk (Trichuris trichiura), cacing ini tersebar luas di daerah tropis dan berhawa panas berbentuk mirip cambuk; Ancylostoma duodenale; cacing tambang (Necator americanus), dan cacing kremi (Enterobius vermicularis). ${ }^{4-6}$ Prevalensi kecacingan di Surabaya masih tercatat cukup tinggi yaitu sekitar 36\%.

Infestasi cacing pada manusia dipengaruhi oleh perilaku, lingkungan, tempat tinggal, dan manipulasinya terhadap lingkungan. Kecacingan banyak ditemukan di daerah dengan kelembaban yang tinggi. Selain itu, faktor kelompok masyarakat dengan higine perorangan dan sanitasi dasar perumahan yang kurang baik juga dapat menyebabkan terjadinya kecacingan. Penularan kecacingan dapat terjadi melalui beberapa jalan, yaitu telur infektif masuk ke mulut bersama makanan dan minuman yang tercemar melalui tangan yang kotor tercemar terutama pada anak. $6-8$

Berdasarkan latar belakang tersebut maka perlu dilakukan studi untuk mengurangi masalah kecacingan yang saat ini banyak terjadi di Indonesia maupun Surabaya. Peneliti bermaksud menganalisis hubungan antara kontaminasi tanah oleh cacing Ascaris lumbricoides, Trichuris trichiura, Ancylostoma duodenale, Necator americanus, dan Enterobius vermicularis serta kejadian infeksi kecacingan pada anak balita.

\section{Metode}

Penelitian ini menggunakan desain studi kasus kontrol di Kampung Keputih Kecamatan Sukolilo Surabaya dalam periode 3 bulan yaitu bulan Maret hingga Mei 2010. Kampung Keputih dahulu adalah kawasan tempat pembuangan akhir (TPA) sampah di Surabaya, tetapi sejak tahun 2000 kawasan TPA ini ditutup. Sejak saat itu, Kampung Keputih digunakan sebagai perkampungan khususnya para pemulung dan keluarganya. Populasi penelitian adalah anak-anak berusia 1 - 5 tahun yang tinggal di wilayah Kecamatan Sukolilo Surabaya. ${ }^{9}$ Sampel dalam penelitian adalah anak-anak berusia $1-5$ tahun yang meliputi kasus dan kontrol. ${ }^{9}$ Kasus adalah anak sehat dengan tinja positif telur atau larva cacing perut dengan pemeriksaan tinja metode hapusan langsung dengan larutan $\mathrm{NaCl}$ (metode Willis). ${ }^{6}$ Kriteria inklusi meliputi: anak balita (usia 1 - 5 tahun) dalam keadaan sehat tidak menderita diare atau disentri, bertempat tinggal di wilayah Kampung Keputih Kecamatan Sukolilo Surabaya, mendapat izin dari orang tua. Kontrol adalah anak sehat yang di dalam tinjanya tidak terdapat telur atau larva cacing.

Besar sampel dihitung dengan menggunakan rumus ukuran sampel untuk desain kasus kontrol. Pada penelitian ini, jumlah kasus sebanyak 63 responden dan kontrol sebanyak 65 responden. Variabel yang diteliti meliputi sanitasi dasar perumahan yang meliputi 4 subvariabel yaitu penyediaan air bersih, sarana jamban, lantai rumah, dan sarana pembuangan sampah menggunakan lembar observasi. Karakteristik responden meliputi usia, jenis kelamin, pendidikan, pekerjan, pendapatan orang tua, serta higiene perorangan meliputi kebiasaan mencuci tangan, kebiasaan memotong dan membersihkan kuku, kebiasaan menggunakan alas kaki, dan kebiasaan mandi. Kelembaban udara diukur dengan higrometer dan suhu ruangan diukur dengan termometer ruang. Analisis menggunakan analisis univariat, bivariat dengan uji chi square, dan multivariat dengan uji regresi logistik. ${ }^{9}$

\section{Hasil}

\section{Analisis Bivariat}

Pemeriksaan telur pada tinja dengan menggunakan metode hapusan langsung dengan larutan $\mathrm{NaCl}$ (metode Willis) dilakukan pada 57 responden kasus dan 63 responden kontrol pada balita. Kejadian kecacingan berdasarkan pemeriksaan telur atau larva cacing menggunakan metode hapusan langsung dengan larutan $\mathrm{NaCl}$ (metode Willis) dalam tinja pada anak balita didapatkan pada $43 \%$ dari 126 anak balita yang diperiksa tinjanya. Proporsi telur atau larva positif pada kelompok kasus $(36,7 \%)$ lebih besar dibandingkan kelompok kontrol $(28,3 \%)$. Kelompok kasus yang menggunakan penyediaan air bersih $(73,3 \%)$ lebih kecil dari kelompok kontrol $(26,7 \%)$. Sarana sanitasi pembuangan kotoran (jamban) yang tidak memenuhi syarat pada kelompok kasus $(56,0 \%)$ lebih besar dari kelompok kontrol $(44,0 \%)$. 
Tabel 1. Hubungan Variabel Penelitian dengan Kejadian Kecacingan pada Anak Usia di Bawah Lima Tahun

\begin{tabular}{|c|c|c|c|c|c|c|}
\hline Variabel & Kategori & $\begin{array}{c}\text { Kasus } \\
(\%)\end{array}$ & $\begin{array}{c}\text { Kontrol } \\
(\%)\end{array}$ & OR & 95\% CI & Nilai $p$ \\
\hline \multirow[t]{2}{*}{ Luas ventilasi rumah } & TMS $(<10 \%$ luas lantai $)$ & 69,1 & 30,9 & 3,520 & $1,445-8,5$ & 0,009 \\
\hline & MS ( $\geq 10 \%$ luas lantai $)$ & 42,9 & 57,1 & & & \\
\hline \multirow[t]{2}{*}{ Kepadatan hunian ruang tidur } & TMS (<4 m²/orang) & 56,0 & 44,0 & 1,667 & $0,796-3,200$ & 0,179 \\
\hline & MS ( $\geq 4 \mathrm{~m}^{2} /$ orang) & 47,9 & 52,1 & & & \\
\hline \multirow[t]{2}{*}{ Suhu dalam kamar } & TMS/tidak nyaman $\left(<18^{\circ} \mathrm{C} />30^{\circ} \mathrm{C}\right)$ & 59,1 & 41,9 & 2,678 & $0,890-8,005$ & 0,122 \\
\hline & MS/nyaman $\left(\geq 18^{\circ} \mathrm{C}-30^{\circ} \mathrm{C}\right)$ & 44,9 & 55,1 & & & \\
\hline \multirow[t]{2}{*}{ Kelembaban dalam kamar } & TMS $(<40 \%$ atau $70 \%)$ & 59,9 & 40,1 & 1,705 & $0,879-8,050$ & 0,131 \\
\hline & $\operatorname{MS}(40 \%-70 \%)$ & 37,5 & 62,5 & & & \\
\hline \multirow[t]{2}{*}{ Jenis lantai } & TMS berupa tanah tidak diplester & 56,5 & 43,5 & 2,681 & $0,554-3,550$ & 0,000 \\
\hline & MS plester, ubin, keramik ( $40 \%-70 \%)$ & 48,8 & 51,2 & & & \\
\hline \multirow[t]{2}{*}{ Keberadaan jamban } & Tidak ada & 56,0 & 4,0 & 5,525 & $2,710-8,327$ & 0,000 \\
\hline & Ada & 37,9 & 62,1 & & & \\
\hline \multirow[t]{2}{*}{ Sumber air bersih } & Tidak ada & 73,3 & 26,7 & 3,511 & $1,457-8,609$ & 0,007 \\
\hline & Ada & 43,6 & 56,4 & & & \\
\hline \multirow{2}{*}{ Kebiasaan BAB } & Tidak di jamban & 52,8 & 47,2 & 2,268 & $0,897-8,044$ & 0,000 \\
\hline & Di jamban & 29,4 & 70,6 & & & \\
\hline \multirow[t]{2}{*}{ Kebiasaan penggunaan alas kaki } & Tidak biasa & 86,8 & 13,2 & 31,765 & $8,467-11,00$ & 0,181 \\
\hline & Biasa & 21,7 & 78,3 & & & \\
\hline \multirow[t]{2}{*}{ Mencuci tangan sehabis $\mathrm{BAB}$} & Tidak biasa & 86,4 & 13,6 & 2,295 & $4,727-15,97$ & 0,000 \\
\hline & Biasa & 33,8 & 66,2 & & & \\
\hline \multirow[t]{2}{*}{ Mencuci tangan sebelum makan } & Tidak biasa & 69,3 & 30,7 & 5,543 & $2,709-11,32$ & 0,111 \\
\hline & Biasa & 29,8 & 70,2 & & & \\
\hline \multirow[t]{2}{*}{ Kebiasaan memotong kuku } & Tidak biasa & 88,7 & 21,3 & 0,682 & $7,868-34,33$ & 0,121 \\
\hline & Biasa & 34,5 & 65,5 & & & \\
\hline \multirow[t]{2}{*}{ Pengetahuan orang tua (ibu) } & Rendah & 69,7 & 30,3 & 5,555 & $2,781-8,786$ & 0,000 \\
\hline & Tinggi & 29,1 & 70,9 & & & \\
\hline
\end{tabular}

Keterangan :

TMS $=$ tidak memenuhi syarat

$\mathrm{MS}=$ memenuhi syarat

Sarana luas ventilasi yang tidak memenuhi syarat pada kelompok kasus $(69,1 \%)$ lebih besar dari kelompok kontrol $(30,90 \%)$. Suhu yang tidak memenuhi syarat pada kelompok kasus $(59,1 \%)$ lebih besar dari kelompok kontrol $(41,90 \%)$. Kelembaban yang tidak memenuhi syarat pada kelompok kasus $(59,90 \%)$ lebih besar dari kelompok kontrol $(40,10 \%)$. Sarana jenis lantai yang tidak memenuhi syarat pada kelompok kasus $(56,5 \%)$ lebih besar dari kelompok kontrol $(43,5 \%)$. Tingkat pengetahuan orang tua (ibu) yang rendah pada kelompok kasus $(69,3 \%)$ lebih besar dari kelompok kontrol $(30,7 \%)$. Kepadatan hunian ruang tidur yang tidak memenuhi syarat pada kelompok kasus $(56,0 \%)$ lebih besar dari kelompok kontrol $(44,4 \%)$. Kebiasaan buang air besar (BAB) yang tidak memenuhi syarat pada kelompok kasus $(52,8 \%)$ lebih besar dari kelompok kontrol $(47,2 \%)$. Pada variabel higine perorangan, kebiasaan mencuci tangan pada kelompok kasus yang tidak memenuhi syarat $(88,7 \%)$ lebih besar dari kelompok kontrol $(21,3 \%)$, kebiasaan memotong dan membersihkan kuku yang tidak memenuhi syarat pada kelompok kasus $(69,3 \%)$ lebih besar dari kelompok kontrol $(30,7 \%)$, kebiasaan menggunakan alas kaki pada kelompok kasus yang tidak memenuhi syarat $(86,8 \%)$ lebih besar dari kelompok kontrol $(13,2 \%)$, kebiasaan mencuci tangan sebelum dan setelah $\mathrm{BAB}$ yang tidak memenuhi syarat pada kelompok kasus $(86,4 \%)$ lebih besar dari kelompok kontrol $(13,6 \%)$ (Lihat Tabel 1).

\section{Analisis Multivariat}

Melului uji regresi logistik dilakukan analisis hubungan variabel dengan kejadian kecacingan Ascaris lumbricoides, Trichuris trichiura, Ancylostoma duodenale, Necator americanus, dan Enterobius vermicularis secara bersama-sama. Ditemukan 5 variabel yang bermakna dengan kejadian kecacingan secara bersama yaitu sarana sanitasi pembuangan kotoran (jamban), kebiasaan BAB tidak di jamban, jenis lantai rumah yang masih berupa tanah, kebiasaan cuci tangan setelah $\mathrm{BAB}$, dan pengetahuan orang tua terutama ibu (Lihat Tabel 2).

\section{Pembahasan}

\section{Kejadian Kecacingan}

Ukuran ventilasi atau luas ventilasi rumah menyebabkan sinar matahari dan pergantian udara ruangan dalam rumah terbatas sehingga tidak cukup mengurangi kelembaban dan kelembaban yang tinggi disukai jenis cacing tertentu. Variabel ventilasi, kelembaban, dan suhu 
Tabel 2. Hasil Analisis Multivariat

\begin{tabular}{llll}
\hline \multicolumn{1}{c}{ Variabel } & Nilai p & OR & 95\% CI \\
\hline Jenis lantai & 0,003 & 5,342 & $3,554-8,550$ \\
Keberadaan jamban & 0,000 & 5,425 & $4,727-15,970$ \\
Kebiasaan BAB & 0,001 & 4,821 & $1,897-7,044$ \\
Mencuci tangan sehabis BAB & 0,007 & 4,654 & $2,710-8,327$ \\
Pengetahuan orang tua (ibu) & 0,003 & 2,425 & $1,781-6,786$ \\
\hline
\end{tabular}

ruangan tidak berhubungan secara bermakna dengan kecacingan. Hal tersebut disebabkan persentase ventilasi, kelembaban, dan suhu yang tidak memenuhi syarat baik pada kasus $(59,1 \%)$ dan kontrol $(41,9 \%)$ tidak menunjukkan perbedaan yang bermakna. Sebagian besar kasus menempati rumah dengan kepadatan hunian ruang tidur yang tidak memenuhi syarat atau kurang. Menempati rumah dengan ruang tidur yang tidak memenuhi syarat ( $<4 \mathrm{~m}^{2}$ /orang) berisiko terjadi penularan kecacingan dibandingkan menempati rumah dengan kepadatan hunian ruang tidur memenuhi syarat. Hal tersebut mungkin disebabkan persentase kepadatan hunian ruang tidur tidak memenuhi syarat baik pada kasus (56\%) dan kontrol $(44 \%)$ sehingga tidak menunjukkan perbedaan yang bermakna.

Sumber air bersih responden didapatkan melalui air perusahaan daerah air minum (PDAM) yang dikirim ke rumah responden melalui gerobak dorong berisi jeriken, yang dikirim secara rutin/setiap hari. Variabel sumber air bersih tidak berhubungan bermakna dengan kejadian kecacingan. Demikian pula variabel cuci tangan dan memotong kuku tidak berhubungan bermakna dengan kejadian kecacingan. Hal ini mungkin disebabkan karena responden memakan makanannya menggunakan sendok atau masih disuapi oleh orang tuanya. Variabel penggunaan alas kaki juga tidak berhubungan secara bermakna karena responden masih banyak yang digendong orang tuanya dan bermain-main di atas tempat tidur kayu di teras rumah. Semua responden dalam kategori ini memiliki jenis lantai plester di ruang tamu dan ruang tidur, tetapi teras dan dapur masih berlantai tanah yang dikombinasikan dengan bata atau batako yang erat kaitanya dengan tanah. Berdasarkan uji multivariat diperoleh hasil bahwa menempati rumah yang berlantai tanah memberikan peluang 5 kali lebih besar dibandingkan dengan rumah plester/tegel/keramik seluruhnya. Hal ini karena pengambilan data pada bulan Maret dan Mei, dimana menurut Badan Meteorologi, Klimatologi, dan Geofisika (BMKG) bulan Oktober - Maret adalah bulan yang bercurah hujan tinggi dan kelembaban tinggi, kelembaban tinggi berpengaruh pada tanah karena air pada tanah yang lembab merupakan media penyebaran telur/larva infektif dari feses ke lingkungan sekitarnya. 1,4

Hasil penelitian sebagian besar kasus tidak mempunyai jamban atau BAB di jamban (56\%) lebih besar dibandingkan kontrol. Hasil uji multivariat menunjukkan bahwa kebiasaan BAB tidak di jamban memberikan peluang 4 hingga 5 kali dibandingkan $\mathrm{BAB}$ di jamban. Berdasarkan uji multivariat, rendahnya pengetahuan orang tua terutama ibu anak balita tentang kesehatan lingkungan dan kecacingan 2 kali lebih besar dibandingkan dengan orang tua yang berpengetahuan tinggi.

Prevalensi kejadian kecacingan pada anak balita di Kampung Keputih Kecamatan Sukolilo Surabaya dalam penelitian ini sebesar 9,8\%. Hasil penelitian ini lebih kecil angka prevalensinya dari hasil penelitian Showkat Achmad Wani, et al, 5 di Gurez-Jammu dan Kashmir State India dimana didapat prevalensi kejadian kecacingan pada 352 anak-anak yang disurvei sebesar 75,28\% menunjukkan lebih dari satu jenis cacing yang menginfeksi seperti prevalensi Ascaris lumbricoides (71,18\%), Trichuris trichiura $(26,42 \%)$, dan Enterobius vermicularis $(13,92 \%)$.

Menurut World Health Organization (WHO), tingkat infeksi kecacingan menunjukkan indeks sanitasi di masyarakat. ${ }^{4,10}$ Keadaan kemampuan sosial ekonomi masyarakat yang rendah menyebabkan kondisi higiene dan sanitasi yang rendah. ${ }^{7,8}$ Kecacingan di negara berkembang seperti Indonesia memang tidak cepat menimbulkan kematian atau case fatality rate (CFR) rendah, tetapi dapat mengganggu tumbuh kembang manusia terutama anak-anak karena adanya gangguan saluran pencernaan sehingga mengganggu nutrisi dan menyebabkan anemia. ${ }^{5}$ Kondisi anemia mengakibatkan produktivitas dalam belajar maupun bekerja menjadi menurun. Kecacingan ditularkan melalui kontaminasi tanah maupun air akibat higiene dan sanitasi yang buruk. Hal ini dapat diperburuk dengan perilaku yang tidak sehat. 1,6,10

Menurut perkiraan WHO, secara global terdapat 800 - 1.000 juta kasus Ascaris dan 7 - 900 kasus Trichurisiasis. $3,11,12$ Untuk di Indonesia, belum ada data prevalensi kecacingan yang pasti dan diperkirakan $40 \%-60 \%$ untuk semua umur dan $60 \%-80 \%$ untuk murid sekolah dasar. ${ }^{2}$ Kebiasaan anak-anak dalam bermain banyak menggunakan sarana tanah sebagai tempat aktivitas sehingga kemungkinan terkontaminasi cacing melalui tanah cukup besar. Risiko terjadinya kecacingan yang ditunjang dengan perilaku membuang tinja sembarangan cukup besar sehingga sarana jamban keluarga sangat diperlukan untuk menurunkan angka kejadian kecacingan.

\section{Faktor yang Berhubungan dengan Kejadian Kecacingan}

Berdasarkan analisis multivariat regresi logistik, variabel yang bermakna dengan kejadian kecacingan adalah sarana sanitasi (jamban), kebiasaan $\mathrm{BAB}$, jenis lantai rumah, kebiasaan cuci tangan setelah $\mathrm{BAB}$, dan penge- 
tahuan orang tua balita terutama ibu mempunyai nilai $\mathrm{p}$ $>0,05$, tetapi secara substansi kebiasaan cuci tangan merupakan faktor penting pada kejadian kecacingan anak balita. Kebiasaan cuci tangan sebelum makan menggunakan air sabun mempunyai peranan penting dalam kaitannya dengan pencegahan infeksi kecacingan karena dengan menggunakan air dan sabun dapat lebih efektif menghilangkan kotoran, debu, dan telur cacing yang menempel pada permukaan kulit dan kuku pada kedua tangan. ${ }^{13}$ Hasil analisis didapatkan odds ratio (OR) variabel sarana sanitasi (jamban) adalah 5,245 dan merupakan variabel dengan nilai OR terbesar yang artinya sarana sanitasi (jamban) merupakan variabel yang berhubungan sangat erat dengan kejadian kecacingan. ${ }^{4,10,14}$

Menurut penelitian Bundhy DA, ${ }^{14}$ dan Albonico et al, ${ }^{1,11}$ penyakit infeksi kecacingan merupakan penyakit yang dipengaruhi oleh keadaan sanitasi lingkungan terutama sarana pembuangan tinja (jamban). Penyakit infeksi kecacingan ditularkan melalui soil transmitted helminthiasis sehingga pembuangan tinja yang memenuhi syarat serta saniter akan mengurangi risiko kejadian penyakit. Salah satu faktor yang dapat mempengaruhi terjadinya penyakit infeksi kecacingan adalah jamban yang tidak saniter. 1,3,8,7 Pembuangan kotoran manusia bila tidak dikelola dengan baik sering mencemari air bersih sehingga air tersebut dapat menyebabkan penyakit atau mencemari permukaan tanah serta makanan. ${ }^{1,7}$ Salah satu perilaku manusia yang berhubungan dengan penyebaran penyakit infeksi kecacingan adalah kebersihan perorangan seperti kebiasaan cuci tangan sebelum makan dan setelah BAB. ${ }^{15}$ Berdasarkan penelitian Albonico et al, ${ }^{1}$ dan $\mathrm{WHO}, 6,10$ tanah dan air yang terkontaminasi telur cacing memiliki peranan dalam kejadian infeksi kecacingan. Telur cacing sampai pada manusia melalui tanah yang terkontaminasi oleh tinja yang mengandung telur cacing infektif. 2,5,8,11,12

Penyediaan air bersih dan jamban keluarga yang tidak memenuhi syarat dapat menjadi faktor risiko terjadinya penyakit infeksi yang ditularkan melalui tanah dan air seperti infeksi kecacingan. Kepemilikan jamban yang baik akan menurunkan prevalensi kecacingan, tetapi hal tersebut harus diikuti dengan perilaku anak, sosial ekonomi, dan sarana air bersih yang baik. ${ }^{15}$ Menurut penelitian Albonico et al, ${ }^{1}$ faktor-faktor yang berperan pada kejadian infeksi kecacingan melalui kontaminasi tanah selain daerah kumuh dengan penduduk yang padat adalah tingkat pendapatan keluarga rendah. Hal ini juga dapat disebabkan karena tingkat pendapatan keluarga di wilayah penelitian hampir merata antara tingkat pendapatan rendah dengan tingkat pendapatan cukup. ${ }^{3,14}$

\section{Kesimpulan}

Prevalensi kejadian infeksi kecacingan dengan pe- meriksaan tinja anak balita adalah 9,8\%. Tanah yang positif telur cacing sebanyak $6,5 \%$. Terdapat hubungan yang bermakna antara sarana sanitasi (jamban) dengan kejadian infeksi kecacingan anak balita dengan nilai OR $=5,245$. Anak balita yang mempunyai sarana sanitasi (jamban) tidak memenuhi syarat mempunyai peluang 5,245 kali terkena infeksi kecacingan dibandingkan anak yang mempunyai sarana sanitasi (jamban) yang memenuhi syarat. Ada hubungan yang bermakna antara kebiasaan cuci tangan anak setelah $\mathrm{BAB}$ dengan kejadian infeksi kecacingan anak balita dengan nilai $\mathrm{OR}=4,821$. Anak balita yang tidak mempunyai kebiasaan cuci tangan setelah $\mathrm{BAB}$ mempunyai peluang 4,821 kali terkena infeksi kecacingan dibandingkan anak yang mempunyai kebiasaan cuci tangan setelah BAB. Ada hubungan yang bermakna antara kebiasaan BAB tidak di jamban kejadian infeksi kecacingan anak balita dengan nilai $\mathrm{OR}=$ 4,654 . Anak balita yang tidak mempunyai kebiasaan $\mathrm{BAB}$ di jamban mempunyai peluang 4,654 kali terkena infeksi kecacingan dibandingkan anak yang mempunyai kebiasaan BAB di jamban. Terdapat hubungan yang bermakna antara rumah berlantai tanah dengan kejadian infeksi kecacingan anak balita dengan nilai $\mathrm{OR}=5,342$. Anak balita yang tinggal di rumah berlantai tanah mempunyai peluang 5,342 kali terkena infeksi kecacingan dibandingkan anak balita yang tinggal di rumah yang tidak berlantai tanah. Ada hubungan yang bermakna antara pengetahuan orang tua, dalam hal ini ibu, dengan kejadian infeksi kecacingan anak balita dengan nilai OR = 2,425 . Rendahnya pengetahuan orang tua/ibu tentang kesehatan lingkungan dengan kecacingan mempunyai peluang 2,425 kali terkena infeksi kecacingan dibandingkan dengan orang tua (ibu) yang berpengetuhan kesehatan lingkungan dan kecacingan yang tinggi.

\section{Saran}

Untuk mengurangi prevalensi kejadian kecacingan diperlukan berbagai upaya antara lain penyuluhan tentang penyakit infeksi kecacingan dan faktor-faktor yang mempengaruhinya kepada orang tua, anak balita, dan kader kesehatan; membangun sarana jamban umum yang memenuhi syarat kesehatan; membiasakan cuci tangan pakai sabun sebelum makan dan setelah BAB; serta memberikan obat cacing sebagai sarana preventif terhadap kecacingan pada anak balita 6 bulan sekali.

\section{Daftar Pustaka}

1. Albonico M, Allen H, Chitsulo L, Engels D, Gabrielli AF. Controlling soil transmitted helminthiasis in pre school age children through preventive chemotherapy. Plos Negl Trop Dis. 2008; 2 (3): e 126.

2. Kementerian Kesehatan Republik Indonesia. Hasil survei morbiditas cacingan tahun 2005. Jakarta: Sub Direktorat Diare dan Penyakit Pencernaan Direktorat Jenderal Pengendalian Penyakit dan Penyehatan Lingkungan; 2005. 
3. Legesse M, Erko B. Prevalence of intestinal parasites among school children in South East of Lake Longano Ethopia. Europ J Health Develop. 2004; 18; 116-20.

4. Achmed B, Bhanti G, Thokar MA, Malla N. Human toxocariasis and ascariasis: Concomitant parasitism in Srinagar Kashmir India. India J Pathol Microbiol. 2002; 45; 315-8.

5. Showkat AW, Fayas A, Showkat AZ, Ayesha A, Zubair AD, Pervaiz AD. Intestinal helminthiasis in children of Gurez Valley and Kasmir State India. Clinical Epidemiolgy. 2010; 2: 91-4.

6. Soedarto. Parasitologi klinik. Surabaya: Airlangga University Press; 2008. halm 71-91.

7. Norhayati M, Oothuman P, Fatimah MS. Some risk factors of ascaris and trichuris infection in Malaysian aborigine children. Med J Mal. 1998: 5; 401-7.

8. Rodrigurez ZR, Lozano CG, Diaz I, Cheng R, Rucson G. Intestinal parasites in schoolchildren at a public institution in Maracaibo Municipality Venezuela. Invent Clin. 2000; 41: 37-57.

9. Lemeshow S. Besar sampel dalam penelitian kesehatan. Yogyakarta: UGM press; 1997. halm 23-30.
10. Srisasi G, Herry DI, Wita P. Parasitologi kedokteran. 3rd ed. Jakarta: Fakultas Kedokteran Universitas Indonesia; 2000. halm 23-26.

11. World Health Organization. Prevention and control of intestinal parasitic infection. Technical Report series 854. Geneva, Switzerland: World Health Organization ; 1997.

12. World Health Organization. Schistosomiasis and soil-transmitted helminth infection preliminary estimates of the number of children treated with albendazole or mebendazole. Wkly Epidemiol Rec. 2006; 16: $145-64$.

13. Umar Z. Perilaku cuci tangan sebelum makan dan kecacingan pada murid SD di Kabupaten Pesisir Selatan Sumatera Barat. Kesmas Jurnal Kesehatan Masyarakat. 2008; 2 (6): 249-54.

14. Bundhy DA, Kan SP, Rose R. Age related prevalence, intestinal, and frequency distribution of gastrointestinal helmints in urban slum children from Kuala Lumpur Malaysia. Trans R soc Trop Med Hyg. 1988; 82: 289-94.

15. Ginting L. Infestasi kecacingan pada anak SD di Kecamatan Sei Bingai Langkat Sumut 2005. Kesmas Jurnal Kesehatan Masyarakat, 2006; 1 (1): $18-25$. 